\title{
The Early History of the Noetic Triad
}

\author{
John Dillon \\ Trinity College Dublin
}

The question of the origins of the Neoplatonic triad of 'moments' or aspects of the intelligible realm, Being, Life, and Intellect proper, first securely attested in Porphyry, but adumbrated already at various points in his works by Plotinus, ${ }^{1}$ is a rather murky one. It is by now, however, I think, generally agreed by those who have taken an interest in the matter that the evidence of a number of Gnostic texts, such as in particular, Allogenes, The Gospel of the Egyptians and Zostrianos, indicates that this formulation must be pushed back well into the second century $\mathrm{CE}$, if not earlier.

Unfortunately, there is a missing link in this tale of influences and sources. Familiar though Porphyry, and even Plotinus, undoubtedly was with certain of the Gnostic texts, such as Zostrianos and Allogenes, ${ }^{2}$ we may regard it as improbable that Platonist philosophers would have borrowed such a doctrine from such a source. The doctrine, after all, seems to derive ultimately from a creative exegesis of a notable passage of Plato's Sophist:

STRANGER: But tell me in heaven's name, are we to be easily con-

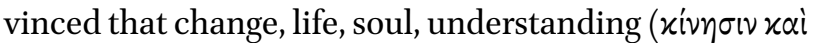

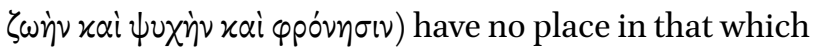
is perfectly real — that it has neither life nor thought, but stands immutable in solemn aloofness, devoid of intelligence?

THEAETETUS: That, sir, would be a strange doctrine to accept.

STRANGER: But can we say that it has intelligence (vovs) without

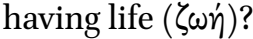

THEAETETUS: Surely not. ${ }^{3}$

Some Middle Platonist exegete, we must suppose-probably subsequent to Plutarch, or we would surely have heard some intimation of this from him-

1 See on this e.g. Hadot 196o.

2 As attested by Porphyry in Vita Plotini, ch. 16.

3 Plato, Sophist, 248e-249a, trans. Cornford.

(C) KONINKLIJKE BRILL NV, LEIDEN, THE NETHERLANDS, 2022 DOI:10.1163/9789004501331_017 
would seem to have derived from this passage the inspiration to postulate that the nature of the cosmic Intellect - which might be for him a first principle or, more probably, a secondary, demiurgic principle — should comprise, not only being and intellection, but also 'life' (which may be taken to include xivnoıs, denoting both 'change' and-spiritual-motion). The problem is, of course, that we have no evidence of any such development in the work of any mainline Platonist or Pythagorean, only in such flowerings of the 'Platonic Underworld' as Sethian Gnostic texts or the Chaldaean Oracles.

Let us have a look at those, then, before venturing any speculations about possible Platonist authorities. If we take our start from the tractate Allogenes, we find the following, ${ }^{4}$ where the Foreigner (Allogenes), in turning inward towards cognition of the Barbelo, which is the primal emanation of the First Principle, ${ }^{5}$ is exhorted to approach the powers within it in a certain order: first, Blessed-

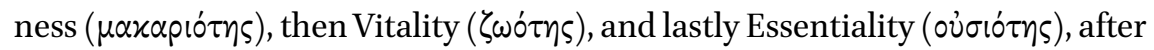
which he will grasp the whole essence of the Barbelo.

In the Gospel of the Egyptians, ${ }^{6}$ on the other hand, we learn that the Great Invisible Spirit emanated three powers, "which it emitted from its bosom in silence" and by its forethought ( $\pi$ póvol $\alpha)$ : the Father, the Mother, and the Son, each of which then generates an ogdoad of aeons. This whole realm (which is initially termed Doxomedôn-Domedôn) is referred to as Barbelo just below, ${ }^{7}$ or at least Barbelo is portrayed as taking a controlling interest in it.

Lastly, in Zostrianos, ${ }^{8}$ the Barbelo is presented as the source of three basic powers, Essentiality, Blessedness and Life-the same triad as in Allogenes, though in a different, descending order. We may note here the oddity of presenting what is the 'lowest' of the three Powers (though listed here first or second),

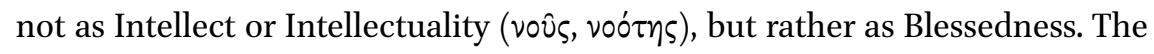
reason for this is not clear, but the Gnostic authors may be shying away from Intellect as a title for the third power as being too 'secular', or even Platonist, while 'blessedness' could be viewed as the consequence of a perfect divine selfconsciousness. It is certainly not uncommon in later Platonism to characterise the state of the realm of Intellect as enjoying $\mu \alpha x \alpha$ piótクs, thus assimilating it to the 'blessedness' of the life of the Homeric gods on Olympus (e.g. Plotinus,

4 Allogenes, 59.1-37.

5 The etymology of this entity is quite obscure, but it may be a garbled version of a Late Egyptian (Coptic) word berber, meaning 'boiling over', or 'overflow', combined with the ending $\hat{o}$, meaning 'great'. This would at any rate suit its situation.

6 Gospel of the Egyptians, 4. 51. 15-52. 24.

7 Gospel of the Egyptians, 4. 54.20.

8 Zostrianos, 14. $1 \mathrm{ff}$. 


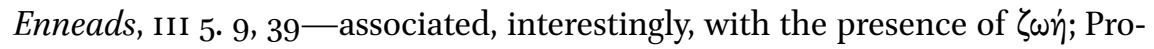
clus, Theologia Platonica III 22, 6). At any rate, $\mu$ axapiótns may be taken here to fill the role of vov s as the third element in the Sethian Gnostic triad. ${ }^{9}$

If we turn, on the other hand, to the Chaldaean Oracles, another salient feature of the 'Platonic Underworld', which are the product of that interesting late second-century figure, Julian the Theurgist (albeit with some help from the Gods of Chaldaea), we find once again a divine triad, identified as 'Father',

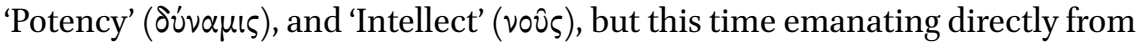
the First Principle in the Chaldaean system, which is the Father, with whom the other two entities are, broadly, co-ordinate, and remain closely connected. We have a number of references to this, from various perspectives. In Fr. 3 Des Places, for a start, we find the following utterance (quoted by Michael Psellus), ${ }^{10}$ referring to a moment of transcendence on the part of the Father:

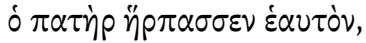

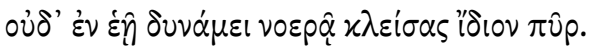

The Father snatched himself away,

No longer enclosing his proper fire within his intellectual potency.

More normally, however, the Father holds his Potency close to him, while distancing himself somewhat from his Intellect, as described in Fr. 4, quoted by Proclus (In Alcibiadem, 84, 12-14), with the comment: "For everywhere potency has been allotted the middle place: among the intelligibles, it unites the Father and the Intellect":

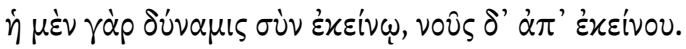

For his Potency is with him, but Intellect stands away from him.

9 A further very odd detail may be noted here, though the passage will be discussed in greater detail below. The fourth century Christian Platonist Marius Victorinus, in his treatise Adversus Arium (I 52, 1-10), in presenting the noetic triad (which he employs as a means of elucidating the relations between Father, Son and Holy Spirit), lists the moments

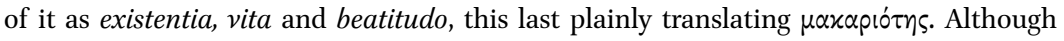
Marius is fairly plainly dependent for much of his terminology on Porphyry, as argued by Pierre Hadot (Hadot 1968), this detail, for which there is no evidence in Porphyry (though Porphyry was well acquainted with the treatises of Zostrianos and Allogenes), may well betoken some familiarity on Marius' part with Gnostic sources, as argued for by Michel Tardieu (Tardieu 1996).

In Patrologia Graeca 122, 1144a8-9. 
While I do not see that this $\dot{\alpha} \pi$ ' implies any great degree of separation between the Father and his Intellect, it is notable that the third element of the triad is seen as more distinct from the first than is the second. This impression is reinforced by a number of other fragments $(5,7)$, in which the Father is portrayed as in some way delegating the task of creation to Intellect. In Fr. 5 , from Proclus' Timaeus Commentary (II 57.30-58.3), we find the following:

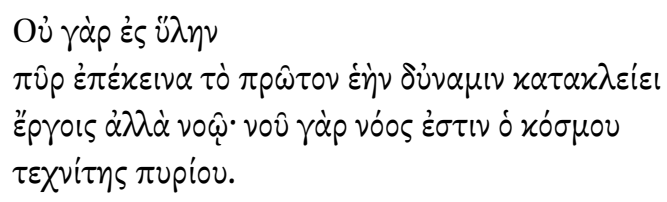

For the primal transcendent Fire does not enfold its own power into matter by actions, but by intellect. For intellect sprung from fiery ${ }^{11}$ intellect is the craftsman of the world.

The distinction here made between the 'fiery vov̂s', who is to be taken as identical with the Father-or rather, perhaps, as the whole paternal triad - and a secondary vovs, who is the immediate creator of the universe, brings the Chaldaean metaphysical system interestingly close to that of Numenius, who would be Julian's older contemporary.

In Fr. $7{ }^{12}$ the distinction is made even clearer: "For the Father brought all things to completion, and handed them over to the Second Intellect (vovs $\delta \varepsilon v$ $\tau \varepsilon$ роऽ), which you, the whole race of men, call the first." This nice piece of Chaldaean one-upmanship could be seen as directed, not just at the general run of humans, but also at the majority of Platonist philosophers, who would postulate a supreme demiurgic Intellect, with no further principle above it.

For the Pythagoreanizing Platonist philosopher Numenius, however, there is precisely such a higher Intellect, who delegates the business of creation to a secondary Intellect, and he is prepared to attribute this insight to Plato himself. At any rate, at Fr. 17 Des Places, taken by Eusebius from Book vi of Numenius' treatise On the Good, we find the following, where Numenius actually portrays Plato as addressing the general run of mortals in very much the same terms as do the gods of Chaldaea:

11 I take $\pi$ upiou here, despite the word order, to refer back to vov̂, not to xó $\mu \circ 0 v$, as against the translations of Des Places and Majercik, for example, as the reference here is not to the creation of the empyrean, but rather to that of the physical cosmos.

Quoted by Psellus (in Patrologia Graeca 122, 1140c10-11). 
Since Plato knew that among men the Demiurge is the only divinity recognized, whereas the Primal Intellect, which is called 'Being in itself', is completely unknown to them, for this reason he spoke to them, as it were, as follows: 'O mortals, that Intellect which you have in mind is not the first, but there is another Intellect prior to this one, who is more senior

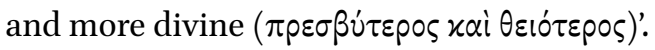

The question of who - the Gods or Numenius - is the earlier is a vexed one, ${ }^{13}$ but I would tend towards Numenius. ${ }^{14}$ If that be accepted, we may be a step nearer to identifying the Platonist source of the application of the triad discerned in Sophist 248E to the first principle, though unfortunately there is no trace of such a formulation in Numenius' surviving fragments. In the search for a Platonist origin of this doctrine, though, he seems to constitute the best bet, ${ }^{15}$ especially since he is agreed to be a major source for the philosophy of both Plotinus and Porphyry, despite their firm rejection of his rather radical metaphysical dualism, and their elevation of their first principle to a status above any form of intellection. In our pursuit of the development of the doctrine of the noetic triad, therefore, it is to Porphyry that we may now turn.

The concept of a noetic triad was not unknown to Plotinus, as we can see from various passages in his works (e.g. Enneads V 4, 2; V 5, 1; v 6, 6; vI 6, 8), ${ }^{16}$ but he was not inclined, for whatever reason, to adopt it into his philosophical system in any formal way, though he certainly makes use of it informally. With his pupil Porphyry, however, it comes into its own as a significant metaphysical formulation, as indeed it continued to be for all later Platonists. Porphyry himself, though, hews much closer to the Chaldaean version of the triad, and in particular, the relation of the Father to the other two members, than any of his successors, with interesting and distinctive results, as we shall see.

We had best start with a rather summary report from Damascius, ${ }^{17}$ where in the course of contrasting the elaboration of the metaphysical system of Por-

13 E.R. Dodds favours the Gods; A.-J. Festugière and Jan Waszink would plump rather for Numenius. Cf. Dodds 196o; Festugière 1951; Waszink 1966.

14 I grant to Dodds that such pompous addresses to humanity are more suited to the Gods, but Numenius, I think, is a man quite capable of bombast on his own account. Dodds 1960, p. 11.

15 Other possibilities would be Atticus, Severus or Harpocration of Argos, but we know much less about any of them, unfortunately, than we do about Numenius.

16 On this subject, see Hadot 196o, p. 107-157.

17 Damascius, De Principiis, ch. 43, I 86, 8-15. 
phyry with that of Iamblichus, he tells us that, for Porphyry, "the single first principle of all things is the Father of the noetic triad" ( $\tau \dot{\eta} \nu \mu i \alpha \nu \tau \hat{\omega} \nu \pi \dot{\alpha} \nu \tau \omega \nu$

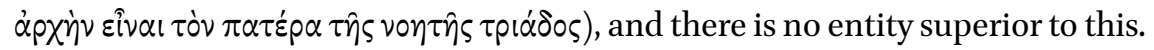
In case we might be tempted to suppose that Damascius is distorting the situation here in order to set up a rhetorical contrast with Iamblichus (whom he portrays as postulating not one, but two 'Ones' superior to the intelligible realm), we find the same allegation directed against Porphyry (though without explicit attribution) by Proclus in his Parmenides Commentary, ${ }^{18}$ at the same time introducing into the mix another key Platonic text in this connection, over and above Soph. 248E, that is to say, the first two hypotheses of the second part of the Parmenides, and specifically the beginning of the second hypothesis $(142 B)$ :

We shall therefore be very far from making the primal god the summit of the intelligible world, as I observe to be the practice of some leading authorities on divine matters, and making the Father of that realm the same as the cause of all things. For this entity is a participated henad. After all, he is called an 'intelligible father', and the summit of the intelligible world, and even if he is the principle of coherence for the whole intelligible world, yet it is as its father that he is so. The primal god who is celebrated in the First Hypothesis is not even a father, but is actually superior to all paternal divinity. The former entity is set over against his 'power' and his 'intellect', of whom he is said to be the father, and with those it makes up a single triad, whereas the truly primal god transcends all contrast and relationship with anything, so that a fortiori it is not an intelligible father. (my trans.)

There can be no doubt, I think, that Porphyry is the subject of this criticism, since no one else fills the bill. The issue, however, now becomes the interesting one of the relationship of the 'One' of the first hypothesis to the 'One-Being' which is the subject of the second. For Plotinus, and for all other Platonists after him except Porphyry, the subject of the two hypotheses are the (supra-essential and supreme) One and the cosmic Intellect (as 'One-Being') respectively. Only Porphyry, it seems, chooses to take the subject-matters as referring to the same entity under two different aspects: the first hypothesis, with its accumulation of negations, refers to the One 'in itself', in its transcendent and ineffable aspect; but the second, with its adducing of 'being' and consequent accretion of posi- 
tive features, represents, not primarily Intellect, but rather the One in its positive, world-creative aspect, which subsumes into itself both 'Life' or 'Potency', and Being/Intellect—and that is why it is also the Father of the noetic triad.

Porphyry does, after all, in many passages scattered throughout his surviving works, ${ }^{19}$ recognise the Plotinian doctrine of the supreme principle being a One above Being and Intellect - as indeed befits the faithful disciple of Plotinus and editor of the Enneads - but he was also plainly concerned with what one might term 'the other half' of Plotinus' concept of the One, the One as 'potency' ( $\delta \dot{v} v \alpha \mu \zeta)$ and 'fount' ( $\pi \eta \gamma \eta$ ) of all creation, and the precise mechanism of this cosmogonic process. The problem of reconciling this aspect of the One with its total transcendence and 'otherness', which Plotinus leaves largely unaddressed, resolved itself for him into the question of the true relationship between the 'ones' of the first and second hypotheses of the Parmenides.

We may discern his hand, I think, lurking beneath a testimony preserved, once again, by Damascius, in a later part of the De Principiis, ${ }^{20}$ as to the exegesis provided by Syrianus and Proclus of the opening line of the Second Hypothesis of the Parmenides (142b5-6: "If One is, is it possible for it to be, and not

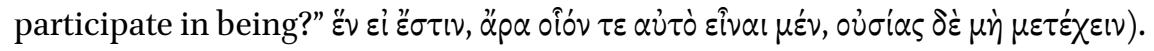
What Damascius tells us is this: the One which is the subject of the Second Hypothesis is not, according to this line of exegesis, the One in its pure state

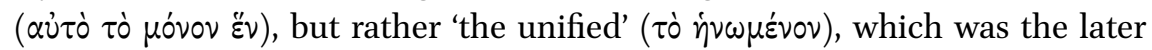
Neoplatonist term for the lowest element of the henadic realm, the product of Limit and Unlimitedness, which also serves as the presiding monad of the intelligible world. This entity is a sort of 'one', but it is not the real thing. Nevertheless, it can be termed 'One', by contrast with Being, with which it forms a relationship ( $\left.\sigma \chi \chi_{\varepsilon}^{\prime} \sigma \iota \varsigma\right)$. This One, Being, and the relationship between them, Syrianus and Proclus discern as forming a triad, the first triad of the intelligible

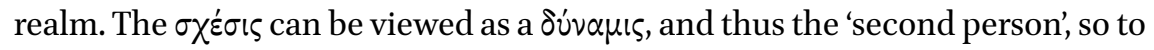
speak, of a Chaldaean-type trinity, while Being can be taken as filling the role of Intellect (vov̂s).

Now it seems to me not improbable that Syrianus and Proclus did not conjure up this triad out of nothing. I would suggest, in fact, that they found

19 E.g. Porphyry, Sent. 43, the whole of which is devoted to demonstrating that Nous cannot be the first principle, because it is multiple and requires a unity prior to it; or Sent. 10, 12 and 25, where the $\dot{\varepsilon} \pi \dot{\varepsilon} x \varepsilon เ \nu \alpha$ ( $\tau \circ \hat{v}$ v०v̂) is clearly distinguished from Nous, in just the way Plotinus would distinguish the One from it. Various fragments of the Philosophic History, also, dealing with the doctrine of Plato (Frs. 220-223 Smith), fully recognise a transcendent One superior to Intellect.

Damascius, De Principiis, ch. 48, II 17. 3 ff. 
already in place in the exegesis of the dialogue by Porphyry. What they would not have approved of, however, in this would be the doctrine that the 'One' which is the subject of the Second Hypothesis, and which is the first element, or 'Father' of the triad that seems to emerge from this passage, is not essentially different from the One which is the subject of the negations of the First Hypothesis, but rather is a representation of it in its outward-flowing, creative aspect.

With this conjecture in mind, then, let us turn to a consideration of certain passages of the (still officially anonymous) Parmenides Commentarywhich, however, I am persuaded, on the basis of both philosophical and linguistic considerations, merits attribution to Porphyry, as was first proposed by Pierre Hadot. ${ }^{21}$ What we find here, in Frs. $5^{-6}$ (ss. XI-XIV Hadot), along with many references to a supreme principle which is a One, is a number of most interesting formulations concerning its relations with what follows it.

First of all, let us take Fr. 5, which seems to concern the beginning of the Second Hypothesis, which we have just been considering. When the fragment begins, Porphyry is making the point that, when One is brought into relation with Being, we must recognise that neither One nor Being can retain their 'pure'

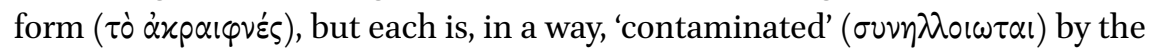
other. ${ }^{22}$ What we find here is the interesting argument that each element even of a logical definition, like 'animal' and 'rational', experiences a sort of 'contamination' when brought into union with the other, sc. to form the definition of 'man'; that is to say, a rational animal is no longer an animal like any other, and an embodied rational entity becomes thereby differentiated from all other rational entities, when combined in the definition of 'man'; and such is the case with 'one' and 'being', when brought into combination with one another. This secondary One, then, both is and is not the same as the 'pure' One. The text continues:

21 I am not persuaded by the gallant effort of Gerald Bechtle (Bechtle 1999) to grant it a pre-Plotinian, Middle Platonic provenance-despite having approved the doctoral thesis behind it, as external examiner! There are just too many tell-tale linguistic details, as well as the not-incompatible doctrinal content, which link it to Porphyry.

A form of this argument in fact turns up in Damascius, De Principiis, I 35, 108. 14-15 Westerink-Combès, in the course of his discussion of the possibility of procession from the One, using the term terms $\dot{\alpha} x p \alpha i \varphi v \varepsilon \dot{s}$ and $\sigma u v \alpha \lambda \lambda_{0}{ }^{\circ} \omega$. Both these key terms are in fact well attested in Porphyry's surviving works, $\alpha x \rho \alpha \iota \varphi v \dot{s} \varsigma$ occurring fully seven times, and

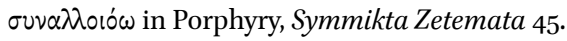


But since it is from that, it is on the one hand certainly One, too; but because it is not that, this whole thing is One-Being, whereas that is One alone. For how could One change into One unless the One were

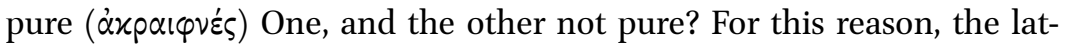
ter both is and is not that (sc. the first One) at the same time, because that which comes after something and is derived from something is, in a way, that from which and after which it is, and it is also something else, which is not only that from which it is, but may also be seen as possessing the contrary attributes. And so, in this case, that is One

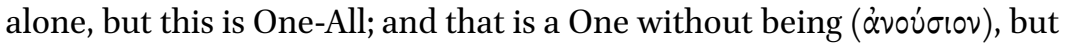
this is a One endowed with being ( $\varepsilon^{2} v v^{\prime} \sigma(o v) ;{ }^{23}$ and being endowed with being and being 'essentialized' ( $\delta \cup \sigma \omega \hat{\omega} \sigma \theta \mathrm{\alpha l})^{24}$ are what Plato means by saying that it 'participates in being' (142b6); not, we may note, postulating Being and then saying that Being participates in Being, but postulating One, but a One that is essentialized-he says that that participates in Being. ${ }^{25}$

The argument goes on some way longer-Porphyry is a man who likes to drive a point home at some length-but we may pass on to Frag. 6. Despite the emphasis on participation, we may note, we have not so far found any mention of a noetic triad, in which this participation would constitute a middle term. However, if we turn to the sixth and final fragment of the Commentary, this deficiency is to some extent rectified. This passage seems to be part of an exegesis of Parmenides 143a3-9, where the subject is the postulation of a third

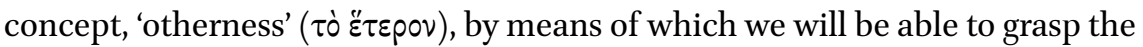
difference between One and Being - this postulation of a third entity in turn leading to the generation of the number series, and so of the whole ordered universe.

Porphyry, when we join him, is engaged on a discussion of the need for a third factor, even in the case of a self-thinking intellect (borrowing here, perhaps, some inspiration from Plotinus' speculations in Enneads v 3 ), in virtue of which one can make the distinction between the thinking and the thought ele-

23 This pair of adjectives, we may note, is found nowhere else in extant Greek literature, but only in the Adversus Arium of Marius Victorinus (I 50. 24-25), a work imbued with Porphyrian metaphysics.

24 This rare term, it may be noted, is also found at Porphyry, Sent. 39, 8; 41, 2, 3, 8; and In Cat. 99, 7 Busse.

25 In Parmenidem XI 29-XII 10 (my trans.). 
ment within such an intellect. He then (XIII $23 \mathrm{ff}$.) adduces Aristotle's concept of the 'common sense' ( of the various particular senses. From that he turns back to the topic at hand, which is the problem of differentiating between One and Being, and indeed between the One in its purity and the One that is in conjunction with Being. It is this latter One, through being 'contaminated' with Being, that generates a triad of Existence, Life and Intelligence which is the subject of the Second Hypothesis:

And so, through being one and simple, 'this itself' (143a9) nevertheless differs from itself in activity and existence ( $\kappa \alpha i \dot{\imath} \pi \dot{\alpha} \rho \xi \xi \iota)$, and it is thus one and simple ( $\dot{\alpha} \pi \lambda \circ 0 \hat{v})$ in one aspect, but differs from itself in another, for that which differs from the One is not one, and that which differs from the simple is not simple. Thus it is one and simple according to its first aspect (idea) - that is, according to the aspect of the

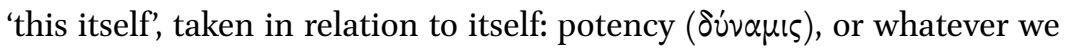
are to call it, merely for the sake of identification, ineffable and inapprehensible as it is, but not one and not simple on the level of exis-

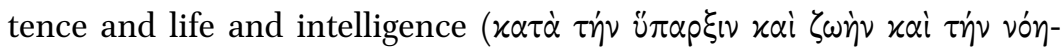
$\sigma(v)$.

- that is to say, in its role as Father of the noetic triad. Porphyry now goes on to set out in more detail the respective functions of the three elements of this triad:

Both the element that thinks and that which is thought enjoy existence, but the thinking element, if intellect passes from existence to the thinking element in order to return to the intelligible and to see itself, is in life. ${ }^{26}$

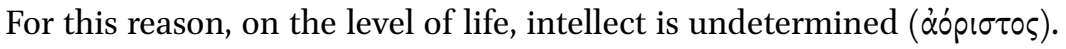

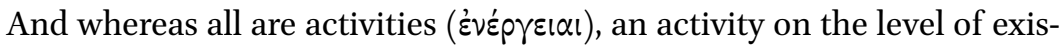
tence is an activity at rest ( $\dot{\varepsilon} \sigma \tau \hat{\omega} \sigma \alpha)$, an activity on the level of thinking is an activity turning towards itself, and one on the level of life is an activity descending $(\dot{\varepsilon} \varkappa v \varepsilon v \dot{\sigma} \sigma \alpha \sigma \alpha)$ from existence. And in this aspect it is at the same time at rest and in motion (145e $7^{-146 a 8)}$, is in itself and in another (145b6-e6), is a whole and has parts (144e8-145a4), and is the same and is different (146a9-147b8); but in that aspect that is purely and simply one,

26 Or perhaps, 'in the mode of vitality'? Porphyry uses the simple dative here. 
and, as it were, firstly and really one, it is neither at rest nor in motion (138b8-139b4), neither the same nor different (139b5-e6), neither in itself nor in another $\left(138 \mathrm{a} 2-\mathrm{b}_{7}\right) \cdot{ }^{27}$

The text tails off just after this, but we have enough here to derive a pretty good idea of what Porphyry's position was. The subject of the First Hypothesis is the One 'in itself', representing the utterly transcendent negative aspect of the Plotinian One. The subject of the Second Hypothesis, however, is not simply, as it was for Plotinus, and all Platonists after Porphyry, Intellect, but rather the One in its positive, emanative aspect, which unfolds itself into a triad through uniting with Being, this triad being expressed, in terms of Chaldaean theology, as Father, Potency or Life, and Intellect. Pure Being, thought of independently of its being joined with One-ness, must be regarded as something indefinite

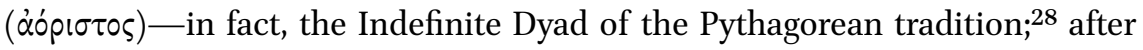
joining with the One, it becomes Intellect, even as the very process of joining, the $\sigma \chi \varepsilon \dot{\varepsilon} \sigma \varsigma$, becomes Potency or Life.

This, then, is the position that the concept of the noetic triad has attained in the philosophy of Porphyry, which may be regarded as the last stage of its 'pre-history' in the later Platonist system. A word might be said in conclusion, however, of the manifestations of the Porphyrian scheme that appear in the fourth-century Roman Christian philosopher Marius Victorinus (fl. 354), on the one hand, and the (more or less contemporary) Cappadocian Christian theologian Gregory of Nazianzus (329-390), in either case in the interest of elucidating the relations between the persons of the Christian Trinity, for which purpose Porphyry's version of the noetic triad is useful in a way that later Platonist versions are not, simply because Porphyry relates the triad to the First Principle.

First of all, Marius, at Adversus Arium I 42, 1-15 (as mentioned above in n. 4), makes the following statement about the nature of God:

God is the potency (potentia) of those three powers, existence, life, and blessedness - that is, what it is to be existent, what it is to be living, and what it is to intelligize (quod est esse, quod vivere, quod intellegere) ${ }^{29}$ That each of these three should be in all is evident; and that Being is first, and

27 In Parmenidem XIV 4-34 (my trans.).

28 Of which, indeed, there are some intimations in Plotinus, e.g. Enneads v 1. 5, 7-9.

29 This is an interesting formulation, doubtless borrowed from his Greek source. 
that this first being, just in so far as it is being, is life and intellect, though without any unification, but simply, in a state of simplicity, that also in demonstrably evident. (my trans.)

It is surely evident where Marius is coming from here, and we can observe in this how useful Porphyry's formulation of the role of the noetic triad can be to Christian theologians.

Another interesting example of this comes from the Third Theological Oration (Oration 29) ${ }^{30}$ of Gregory of Nazianzus, in which he is concerned with refuting the Eunomians, who asserted a strong version of Arianism, to the effect that Son is of a quite different nature to the Father (not even 'like' him!). Eunomius is thus, if anything, reflecting Middle Platonist doctrine about the distinction between the first and second gods-transcendent First Principle and Demiurge. Gregory, in turn, seems, in countering him, to be making use-if somewhat creative use - of the Porphyrian doctrine of the relationship between the Father, his Power, and his Intellect.

In ch. 2 of the Oration, Gregory begins his exposition with a striking phrase: "For this reason, (God), initially a monad, and moving into a dyad, comes to

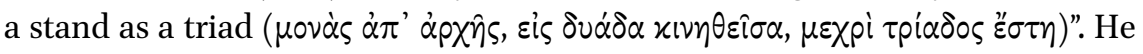
goes on to gloss this remarkable statement by saying, "that is, on our terms, the Father, the Son and the Holy Spirit." This in turn would be troublesome, if this order were taken strictly, since it is properly the Holy Spirit that should be the dyadic, processive element in the triad, but this in fact it turns out to be just below, where the Monad is described as 'Sire' ( $\left.\gamma \varepsilon v \eta^{\prime} \tau \omega \rho\right)$ of the Son, but

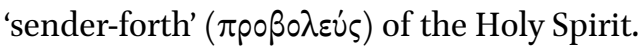

What we have here, then, is the Plotinian-Porphyrian process of Rest, Pro-

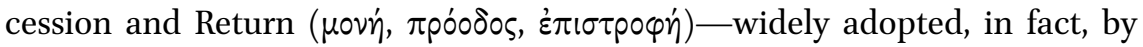
all the Cappadocian Fathers-applied to the relationship between the three 'moments' within the noetic triad: the Son, as Nov̂s, brings the indefinite, 'dyadic' procession of Potency (the Holy Spirit) to a halt by reverting on its source, which, by virtue of being reverted upon, becomes the Father. Gregory is particularly insistent, in view of his opposition to the Eunomians, that Son-ship (and indeed Spirit-ship) involves no inferiority, temporal or otherwise. ${ }^{31}$

The only aspect in which he seeks to distance himself from the Neoplatonic tradition is in the matter of the intentionality of this process of 'outflowing' from the Father. "I will not venture," he says, "to speak of an 'overflowing of goodness'

30 I use the edition, The Five Theological Orations of Gregory of Nazianzus, by A.J. Mason, Cambridge, 1899 .

31 Cf. also Theological Orations v 9-10, where this same point is emphasised. 


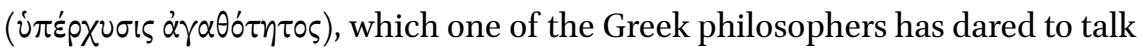
of, like a mixing-bowl ( $p_{p} \tau \tau^{\prime} \rho$ ) overflowing, stating this quite clearly in these terms where he is speaking of the first and second Cause,"32 making an explicit reference here, as Henry and Schwyzer have discerned (ad loc.) to Plotinus, Enn. V 2. 1, where Plotinus precisely talks of the One 'overflowing', without imputing any intentionality to this process. ${ }^{33}$ Gregory repudiates the automatic aspect of this outpouring, as being improper for the personal God of Christianity, at the same time distancing himself prudently from his Platonist sources.

Plotinian metaphysics, then, as filtered through Porphyry's interpretation of it, seems to provide the basis for the philosophical Christian doctrine of the Trinity from Gregory on, since Gregory's formulation seems to have become authoritative, at least in the Eastern Church. Such men as John of Damascus, John of Scythopolis and Maximus the Confessor would appear merely to build

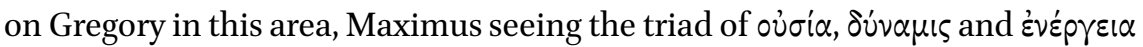
manifested everywhere in the intelligible world. ${ }^{34}$

Lastly, the extensive use by Dionysius the Ps.-Areopagite of triadic formulations to characterise the 'positive aspect' of God, in the Divine Names, esp. chapters 2 and $5^{-7}$, is probably to be derived immediately from his study of the Cappadocian Fathers, but may be seen as going back ultimately to Porphyry. ${ }^{35}$

\section{Bibliography}

\section{Primary Sources}

Anonymous: The Anonymous Commentary on Plato's Parmenides, ed. G. Bechtle, Bern / Stuttgart / Vienna, Paul Haupt, 1999.

The Chaldean Oracles: Text, Translation and Commentary, ed. R. Majercik, Leiden, Brill, 1989; Oracles Chaldaïques, ed. É. des Places, Paris, Les Belles Lettres, 1971.

Damascius, De principiis, ed. C.É. Ruelle, in Damascii successoris dubitationes et solutions, vols. 1 \& 2, Paris, Klincksieck, 1889-1899.

Damascius, Traité des Premiers Principes, 3 vol., texte établi, traduit et annoté, L.G. Westerink, J. Combès, Paris, Les Belles Lettres, 1986-1991.

32 Mason 1899, p. 76, 1.

33 It is interesting, by the way, that Marius also quotes from Enneads v 2, 1, though in a different context, at Adversus Arium IV 22. 8. This little tractate [11], a sort of appendix to v 1 [10], seems to have attracted the attention of Christian intellectuals.

34 See I.P. Sheldon-Williams's useful chapter on Maximus in The Cambridge History of Later Greek and Early Mediaeval Philosophy, p. 492-505.

35 See on this Wear, Dillon 2007, ch. 3: "God as Trinity in The Divine Names". 
Gregory of Nazianzus, The Five Theological Orations of Gregory Nazianzus, ed. and tr. A.J. Mason, Cambridge, Cambridge University Press, 1899.

Marius Victorinus, Adversus Arium, in Marii Victorini Opera. I, Opera Theologica, ed.

P. Henry, P. Hadot, Vienna, Hoelder / Picher / Tempsky, 1971.

Michael Psellus, Opera, ed. J.P. Migne (Patrologia Graeca 122), Paris, 1889.

Nag Hammadi, The Gospel of the Egyptians: in Nag Hammadi codices III, 2 and IV, 2:

The Gospel of the Egyptians (The Holy Book of the Great Invisible Spirit), ed. A. Böhlig,

F. Wisse, P. Labib, Leiden, Brill, 1975.

Nag Hammadi, Nag Hammadi Codex VIII, ed. J. Sieber, Leiden, Brill, 1991.

Nag Hammadi, Allogenes: in J.D. Turner (with O.S. Wintermute), "NHC XI, 3: Allogenes",

Nag Hammadi Codices XI, XII, XIII, ed. C.W. Hendrick: Leiden, Brill, 199o, p. 192-267.

Plato, Sophist: in Plato's Theory of Knowledge: the Theaetetus and Sophist of Plato, tr.

F. Cornford, London, Routledge / Kegan Paul, 1967.

Plotinus, Enneads, ed. P. Henry, H.-R. Schwyzer, Leiden, Brill, 1951-1973.

Porphyry, In Aristotelis Categorias Commentarium, in Porphyrii Isagoge, et in Aristotelis Categorias Commentarium, ed. A. Busse, Berlin, Reimer, 1887.

Porphyry, Vita Plotini, in Plotini opera, ed. P. Henry, H.-R. Schwyzer, vol. I, Leiden, Brill, 1951, p. 1-41.

Porphyry, Symmikta Zetemata, ed. H. Dörrie (Zetemata 20), Munich, C.H. Beck, 1959.

Porphyry, Sententiae ad intelligibilia ducentes, ed. E. Lamberz, Leipzig, Teubner, 1975.

Porphyry, Fragmenta, ed. A. Smith, Stuttgart / Leipzig, Teubner, 1993.

Proclus, In Platonis Parmenidem, in Proclii Philosophi Platonici opera inedita, ed.

V. Cousin, Paris, Minerva, 1864.

\section{Secondary Sources}

Dodds, E.R. (1960), "Numenius and Ammonius", in Entretiens sur l'antiquité classique v: Les sources de Plotin. Genève, Fondation Hardt, p. 3-61.

Festugiére, A.-J. (1951), "La réligion grecque à l'époque romaine", in Revue des études grecques 64, p. 372-393.

Hadot, P. (1960), "Être, vie, pensée chez Plotin et avant Plotin", in Entretiens surl'antiquité classique v: Les sources de Plotin, Genève, Fondation Hardt, p. 107-157.

Hadot, P. (1966), “La métaphysique de Porphyre”, in Entretiens sur l'antiquité classique XII, Genève, Fondation Hardt, p. 127-163.

Hadot, P. (1968), Porphyre et Victorinus, 2 vols. Paris, Etudes Augustiniennes.

Henry, P. (1950), "The Adversus Arium of Marius Victorinus: the First Systematic Exposition of the Christian Doctrine of the Trinity", Journal of Theological Studies, n.s. Vol. 1, p. 42-55.

Sheldon-Williams, I.P. (1967), "Maximus the Confessor", in The Cambridge History of Later Greek and Early Mediaeval Philosophy, A.H. Armstrong (ed.), Cambridge, Cambridge University Press, p. 492-505. 
Tardieu, M. (1996), "Recherches sur la formation de l'Apocalypse de Zostriane et les sources de Marius Victorinus", Res Orientales 9, Paris, Vrin.

Waszink, J. (1966), "Porphyrios und Numenios", in Entretiens sur l'antiquité classique XII, Genève, Fondation Hardt, p. 35-78.

Wear, S.K., Dillon, J. (2007), Dionysius the Areopagite and the Neoplatonist Tradition, Aldershot, Ashgate. 